\title{
Stock Market Efficiency in the Time of COVID-19: Evidence from Industry Stock Returns
}

\author{
Vaibhav Lalwani \\ Indian Institute of Management Raipur, India \\ E-mail: vlalwani@iimraipur.ac.in \\ Vedprakash Vasantrao Meshram \\ Indian Institute of Management Lucknow, India \\ E-mail: fpmI700I@iiml.ac.in
}

Received: July 07, 2020

Accepted: July 30, 2020

Online Published: September 03, 2020

doi: I0.4628I/ijafr.v5i2.744

URL: https://doi.org/I0.4628I/ijafr.v5i2.744

\begin{abstract}
Using industry portfolios as test assets and a battery of statistical tests, we study if the informational efficiency of stock prices has declined after the COVID-I9 crisis began. The results suggest that the predictability of stock returns in some industries has increased during the COVID-I9 period. Markets appear to have become less informationally efficient during the COVID-I9 crisis.
\end{abstract}

Keywords: Covid-I9, Coronavirus, Market Efficiency, Stock Market, Industry Portfolio.

JEL Classification Code: C58, G0I, GI0, GI4.

\section{Introduction}

As nations globally come to terms with a new world order instigated by the coronavirus crisis, the economic outlook in the short term looks uncertain and bleak. This uncertainty can be observed in the sharp volatility in financial markets since the beginning of the year. For example, the S\&P 500 plunged to a low of 2237 on $23^{\text {rd }}$ March just a month after hitting a high of 3386 on 19 ${ }^{\text {th }}$ February. By the end of the quarter, the index was trading around levels of 2600 . This sudden change in price levels warrants attention as it is likely that such large changes could be due to reasons beyond fundamentals. While some believe the panic around the COVID-I9 crisis is overblown ${ }^{\mathrm{I}}$, others maintain that the current situation is the new normal and represents a correction from the impractically high valuations before the COVID situation erupted ${ }^{2}$.

In this study, we formally test if the stock markets have become more inefficient in light of the coronavirus crisis. Proponents of behavioural finance argue that in times of panic or irrational exuberance, asset prices deviate from their fundamental values and this leads to violation of the efficient market hypothesis. The weak form of the efficient market hypothesis states that a market is efficient if prices cannot be predicted using historical price-related information.

Apart from the predictability of stock prices, efficiency testing also has policy implications. Fortune (I99I) argues that inefficiency in stock markets offers an economic foundation for policy interventions by authorities. Mookerjee and Yu (I999) argue that if market inefficiencies are not acted upon by authorities, it could seriously limit the ability of the stock markets to allocate funds to the most productive sectors of the economy and also potentially hamper long-term growth (Kavussanos \& Dockery, 200I).

We specifically test if stock prices show weak form efficiency in the first quarter of 2020 as compared to the last quarter of 2019. The results suggest that the predictability of stock returns has increased during the COVID-I9 crisis, but only for some industries.

The rest of the paper is organized as follows. Section 2 discusses the related literature review. Section 3 describes the data and methodology used in the paper. Section 4 presents the results of empirical analysis. And, Section 5 concludes the study.

${ }^{\text {I }}$ See https://www.marketwatch.com/story/5-reasons-coronavirus-fears-are-overblown-and-I4-stocks-to-buy-now-2020-0I-28 for an example.

${ }^{2}$ See https://www.businessinsider.com/stock-market-sell-off-drop-coronavirus-valuations-start-2020-2?IR =T for an example 


\section{Literature Review}

This study contributes to the literature on asset pricing, informational efficiency, and the impact of pandemics on stock markets. While there is a substantial literature studying the informational efficiency of different asset markets in a general context, little work exists on the impact of COVID-I9 on stock market efficiency, presumably because the crisis is still ongoing. However, some studies have already reported stylised facts about the developments in financial markets after the COVID-I9 crisis. We discuss some of them here.

Haroon and Rizvi (2020) report a sharp increase in asset price volatility in the period of January 2020 to March 2020. They attribute this increase in volatility to the overwhelming panic generated by news outlets. Ali, Alam, and Rizvi (2020), on the other hand, report an increase in volatility in international markets with an increase in deaths. They report this effect across countries and assets. Zhang, Hu, and Ji (2020) also report increased volatility in the markets of the worst affected countries. Using a panel data of Chinese stocks, Al-Awadhi, Al-Saifi, Al-Awadhi, and Alhamadi (2020) report that stock prices are affected negatively by the number of cases as well as deaths. This study contributes to the literature on COVID-I9 and financial markets by testing if market efficiency has declined during the COVID crisis.

\section{Data and Methodology}

For testing the informational efficiency of stock markets in the COVID-I9 period. We collect the data on 12 industry sorted value-weighted portfolios from the Kenneth French's data library. The time spans from I ${ }^{\text {st }}$ October 2019 to $3 I^{\text {st }}$ March $2020 .^{\text {s. }}$ The duration from $I^{\text {st }}$ October 2019 to $3 I^{\text {st }}$ December 2019 is labelled as the pre-COVID period (64 observations) and the period from It $^{\text {st }}$ January 2020 to 3 I $^{\text {st }}$ March 2020 is labelled as the COVID period (62 observations). The COVID period has been chosen from the day that the Chinese authorities first reported about the virus to the $\mathrm{WHO}^{3}$. The objective is to study whether stock prices show any signs of reduced informational efficiency during the COVID-I9 crisis.

The reason to choose industry portfolios is twofold. First, the nature of the crisis and the subsequent policy reaction (such as lockdowns and Federal Reserve actions, etc.) is such that it will affect some sectors more than others. Donadelli, Kizys, and Riedel (2017) also report that the news of infectious diseases has sectoral implications. Second, the selection of industry portfolios reduces the influence of stocks' idiosyncratic risk on the test results.

We examine whether future stock returns can be predicted using past returns using several statistical tests proposed in the literature. The list of tests closely follows that of Urquhart (2016). The first set of tests used are the Ljung and Box (I978) test, the runs test (Wald \& Wolfowitz, 1940), and the Bartels (1982) test. The first test has a null hypothesis of no autocorrelation in the provided time series whereas the next two are non-parametric tests with the null hypothesis that each element in the series is independently drawn from the same distribution. We also use the bootstrapped Automatic variance ratio test of Kim (2009) with a null hypothesis that the price generation process is a random walk. A rejection of the null hypothesis in any of these tests suggests that stock returns can be predicted using past data and provides evidence towards violation of weak-form market efficiency. We also report the rescaled Hurst exponent (R/S Hurst) which is traditionally used to test for persistence in a time series. The R/S Hurst value is corrected for finite sample bias as per Weron (2002). According to Urquhart (2016), values below 0.45 and above 0.65 signal anti-persistence and persistence respectively.

\section{Results}

A cross-sectional study was carried out from $12^{\text {th }}$ February to $27^{\text {th }}$ February 2020. For primary level data, a sample survey was conducted among cobblers. The major portion of the ethnic community lives in Purbachal, Rayer Bazar, Jigatola, Dhanmondi, Savar, and Sutrapur located in Dhaka city. Total 300 number of sample aged between 22 to 60 was randomly selected from the areas like Wari, Shakuria Bazar, Purbachal and Savar, Sutrapur. Targeted people of different locations were requested to cooperate with us to get an interview. A semi-structured pre-tested questionnaire was formatted to collect information on their socioeconomic status including their age, working hours, daily income, expenditures, daily consumption, associated disease pattern, education level, monthly saving, interest to get loans, bank account, banking knowledge, etc. All the collected data were analyzed by using the SPSS v-I6.0 program.

Table I reports the descriptive statistics of the industry portfolios for both the pre-COVID and the COVID periods. One key pattern to note is the sharp increase in volatility (standard deviation) of returns from the pre-COVID to the COVID period. The volatility has seen an over 5 -fold increase for many sectors.

\footnotetext{
${ }^{3}$ See https://www.who.int/emergencies/diseases/novel-coronavirus-2019/events-as-they-happen for a timeline of COVID-I9 related events. 
Table I. Descriptive statistics of the $\mathrm{I} 2$ industry portfolio returns

\begin{tabular}{|c|c|c|c|c|c|c|}
\hline & \multicolumn{3}{|c|}{ COVID } & \multicolumn{3}{|c|}{ PRE-COVID } \\
\hline & Median & Mean & $\begin{array}{l}\text { Standard } \\
\text { Deviation }\end{array}$ & Median & Mean & $\begin{array}{l}\text { Standard } \\
\text { Deviation }\end{array}$ \\
\hline Consumer Non-Durables & 0.13 & 0.09 & 0.49 & 0.04 & -0.29 & 3.22 \\
\hline Consumer Durables & $0.3 \mathrm{I}$ & 0.24 & 0.98 & -0.06 & -0.33 & $4.5 \mathrm{I}$ \\
\hline Manufacturing & 0.16 & 0.10 & 0.78 & -0.17 & -0.47 & 4.04 \\
\hline Energy & 0.08 & 0.09 & 1.26 & -0.58 & -1.02 & 5.15 \\
\hline Chemicals & 0.10 & 0.04 & 0.66 & -0.30 & -0.32 & 3.42 \\
\hline Business Equipment & 0.27 & 0.19 & 0.79 & 0.09 & -0.16 & 3.80 \\
\hline Telecom & 0.15 & 0.09 & 0.60 & -0.01 & -0.32 & 3.12 \\
\hline Utilities & 0.13 & $0.0 \mathrm{I}$ & $0.6 \mathrm{I}$ & 0.13 & -0.24 & 3.98 \\
\hline Shops & 0.14 & 0.07 & 0.57 & 0.00 & -0.18 & 2.99 \\
\hline Healthcare & 0.19 & 0.20 & 0.67 & -0.09 & -0.17 & 2.97 \\
\hline Finance & 0.16 & 0.18 & 0.76 & -0.13 & -0.49 & 4.47 \\
\hline Others & 0.15 & 0.13 & 0.67 & 0.03 & -0.39 & 3.63 \\
\hline
\end{tabular}

Notes: This table reports the mean, median, and standard deviation of daily returns of Fama-French I2 industry portfolios for two periods - pre-COVID ( $\mathrm{I}^{\text {st }}$ September 2019 to $3 \mathrm{I}^{\text {st }}$ December 2020) and COVID (I ${ }^{\text {st }}$ January 2020 to $3 \mathrm{I}^{\text {st }}$ March 2020).

Table 2 reports the results ( $\mathrm{p}$-values) of the mentioned tests for 12 industries for the pre-COVID and the COVID period. As far as the pre-COVID period is concerned, there is very little evidence for any predictability during that period. This suggests informationally efficient markets during the last quarter of 2019 when there was no COVID related threat to global economic activity. These results are consistent across industries.

The efficiency of the market appears to have changed in the first quarter of 2020, the period when COVID related information started appearing in the markets. For 6 out of the 12 sectors, i.e. Manufacturing, Business Equipment, Telecom, and Shops (Wholesale and retail), Finance and others, the market seems to have become inefficient during this period.

Table 2. Results of the tests of Informational efficiency for 12 industry portfolios

\begin{tabular}{|c|c|c|c|c|c|c|}
\hline & & Ljung-Box & Runs-test & Bartels Rank & $\begin{array}{c}\text { Auto Variance } \\
\text { Ratio }\end{array}$ & Hurst R/S \\
\hline \multirow{2}{*}{$\begin{array}{l}\text { Consumer } \\
\text { Durables }\end{array}$} & PRE-COVID & 0.661 & 0.208 & 0.760 & 0.980 & 0.468 \\
\hline & COVID & 0.003 & 0.798 & 0.366 & 0.340 & 0.655 \\
\hline \multirow[t]{2}{*}{ Consumer Durables } & PRE-COVID & 0.286 & 0.608 & 0.125 & 0.020 & 0.744 \\
\hline & COVID & 0.384 & 0.798 & 0.607 & 0.280 & 0.869 \\
\hline \multirow[t]{2}{*}{ Manufacturing } & PRE-COVID & 0.160 & $0.6 \mathrm{I} 4$ & 0.223 & 0.480 & 0.598 \\
\hline & COVID & 0.037 & 0.608 & 0.089 & 0.300 & 0.789 \\
\hline \multirow[t]{2}{*}{ Energy } & PRE-COVID & 0.822 & 0.023 & 0.585 & 0.860 & 0.503 \\
\hline & COVID & 0.067 & 0.798 & 0.243 & 0.360 & 0.764 \\
\hline \multirow[t]{2}{*}{ Chemicals } & PRE-COVID & 0.667 & 0.450 & 0.755 & 0.520 & 0.489 \\
\hline & COVID & $0.00 I$ & 0.298 & 0.368 & 0.180 & 0.438 \\
\hline \multirow[t]{2}{*}{ Business Equipment } & PRE-COVID & 0.672 & 0.801 & 0.588 & 0.840 & 0.355 \\
\hline & COVID & 0.000 & 0.002 & 0.001 & 0.000 & 0.765 \\
\hline
\end{tabular}




\begin{tabular}{|c|c|c|c|c|c|c|}
\hline \multirow[t]{2}{*}{ Telecom } & PRE-COVID & 0.597 & 0.801 & 0.634 & 0.860 & 0.503 \\
\hline & COVID & 0.000 & 1.000 & 0.014 & 0.060 & 0.607 \\
\hline \multirow[t]{2}{*}{ Utilities } & PRE-COVID & 0.119 & 0.078 & 0.076 & 0.180 & 0.621 \\
\hline & COVID & 0.048 & 0.798 & 0.699 & 0.480 & 0.643 \\
\hline \multirow[t]{2}{*}{ Shops } & PRE-COVID & 0.999 & 0.313 & 0.880 & 0.800 & 0.476 \\
\hline & COVID & 0.000 & 0.019 & 0.008 & 0.040 & 0.728 \\
\hline \multirow[t]{2}{*}{ Healthcare } & PRE-COVID & 0.817 & 0.006 & 0.433 & 0.460 & 0.521 \\
\hline & COVID & $0.00 \mathrm{I}$ & 0.124 & 0.210 & 0.140 & $0.57 \mathrm{I}$ \\
\hline \multirow[t]{2}{*}{ Finance } & PRE-COVID & 0.677 & 0.208 & $0.82 \mathrm{I}$ & 0.240 & 0.620 \\
\hline & COVID & $0.00 \mathrm{I}$ & 0.124 & 0.054 & 0.160 & 0.730 \\
\hline \multirow[t]{2}{*}{ Others } & PRE-COVID & 0.406 & 0.896 & 0.652 & 0.300 & 0.601 \\
\hline & COVID & 0.004 & 0.608 & $0.06 \mathrm{I}$ & 0.220 & 0.833 \\
\hline
\end{tabular}

Notes: This table reports the $p$-values for 5 tests of informational efficiency for I2 industry portfolios for the pre-COVID (I ${ }^{\text {st }}$ September 2019 to $3 I^{\text {st }}$ December 2020) and COVID ( ${ }^{\text {st }}$ January 2020 to $3 I^{\text {st }}$ March 2020) periods. P-value lower than 0.I and Hurst exponent values less than 0.45 and greater than 0.65 are highlighted in bold letters. Rejection of the null hypothesis implies that future returns are predictable from past return information.

There is a clear sectoral effect in the declining informational efficiency. These results can be explained by the arguments given in Hong, Torous, and Valkanov (2007). They argue that because very few traders trade in all assets and usually hold undiversified portfolios, markets get segmented, and thus different sectors could react at a different pace to the same information set. Thus, the efficiency of stocks of different sectors could be affected because their investors react differently to the same information.

\section{Conclusion}

With the panic related to COVID-I9 showing its effects in the financial markets, a debate is still raging on about the explanation of the observed reaction of the stock markets. To add to our knowledge of the impact of COVID-I9 on stock markets, we test whether the informational efficiency of the stock market has declined in the months after the COVID-I9 was officially reported as an infectious disease. The findings of the study indicate that the predictability of stock prices has increased for stocks in some industries, namely Telecom, Manufacturing, Business Equipment, Finance, and Shops (wholesale and retail). Thus, the results show that the COVID-I9 crisis has led to increased inefficiency in stock markets.

\section{References}

Al-Awadhi, A. M., Al-Saifi, K., Al-Awadhi, A., \& Alhamadi, S. (2020). Death and contagious infectious diseases: Impact of the COVID-I 9 virus on stock market returns. Journal of Behavioral and Experimental Finance, 100326.

Ali, M., Alam, N., \& Rizvi, S. A. R. (2020). Coronavirus (COVID-I9)-An epidemic or pandemic for financial markets. Journal of Behavioral and Experimental Finance, I0034I.

Bartels, R. (1982). The rank version of von Neumann's ratio test for randomness. Journal of the American Statistical Association, 77(377), 40-46.

Donadelli, M., Kizys, R., \& Riedel, M. (2017). Dangerous infectious diseases: Bad news for Main Street, good news for Wall Street?. Journal of Financial Markets, 35, 84-I03.

Fortune, P. (I99I). Stock market efficiency: an autopsy?. New England Economic Review, I7-40.

Haroon, O., \& Rizvi, S. A. R. (2020). COVID-I9: Media coverage and financial markets behavior-A sectoral inquiry. Journal of Behavioral and Experimental Finance, I00343.

Hong, H., Torous, W., \& Valkanov, R. (2007). Do industries lead stock markets?. Journal of Financial Economics, 83(2), 367396.

Kavussanos, M. G., \& Dockery, E. (200I). A multivariate test for stock market efficiency: the case of ASE. Applied Financial Economics, II (5), 573-579.

Kim, J. H. (2009). Automatic variance ratio test under conditional heteroskedasticity. Finance Research Letters, 6(3), I79-I85.

Ljung, G. M., \& Box, G. E. (1978). On a measure of lack of fit in time series models.Biometrika, 65(2), 297-303.

Mookerjee, R., \& Yu, Q. (I999). An empirical analysis of the equity markets in China. Review of Financial Economics, 8(I), $4 \mathrm{I}-60$.

Urquhart, A. (2016). The inefficiency of Bitcoin. Economics Letters, I48, 80-82. 
Wald, A., \& Wolfowitz, J. (1940). On a test whether two samples are from the same population. The Annals of Mathematical Statistics, II(2), I47-I62.

Weron, R. (2002). Estimating long-range dependence: finite sample properties and confidence intervals. Physica A: Statistical Mechanics and its Applications, 3I2(I-2), 285-299.

Zhang, D., Hu, M., \& Ji, Q. (2020). Financial markets under the global pandemic of COVID-I9. Finance Research Letters, I0I528.

\section{Copyrights}

Copyright for this article is retained by the author(s), with first publication rights granted to the journal. This is an open-access article distributed under the terms and conditions of the Creative Commons Attribution license (http://creativecommons.org/licenses/by/4.0/). 